\title{
The Asset Holdings of the Bank of Japan
}

\author{
Christopher J. Neely, Vice President and Economist
}

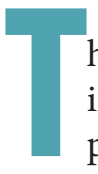
he 2007-09 Financial Crisis and its aftermath reduced inflation to undesirably low levels and raised unemployment to very high levels in many countries. With short-term interest rates at or near zero, conventional monetary policy was limited, and so central banks searched for new ways to stimulate their economies. One such measure was large central bank purchases of long-term bonds to lower long-term yields. Increases in central bank assets are a rough measure of these long-bond purchases. To compare such measures across countries, it makes sense to divide central bank asset holdings by gross domestic product (GDP). This essay compares international asset holdings as a percentage of GDP by major central banks and explains the reasons for the particularly large holdings of the Bank of Japan.

Figure 1 shows asset holdings since 2008 of the four major central banks: the Federal Reserve System (Fed), the Bank of England (BOE), the European Central Bank (ECB), and the Bank of Japan (BOJ). Relative to the size of its economy, the $\mathrm{BOJ}$ is currently the biggest asset holder among these central banks, holding assets worth about 101 percent of Japanese GDP. ${ }^{1}$ The ECB and the BOE currently hold assets valued at 40 percent and 27 percent of the annual output of their respective currency areas. The peak value of the Fed's assets as a percentage of GDP is only 25 percent, which is the smallest such statistic among the four major central banks, and the Fed's balance sheet as a percentage of GDP has been declining since 2014 .

The Bank of Japan purchases large amounts of Japanese government bonds, enabling it to control long-term bond yields.

Figure 1 also shows that the BOJ and the Fed monetary policies have been moving in opposite directions since 2013-14. While the BOJ has been increasing its asset holdings, the Fed has been removing accommodation by allowing its balance sheet to slowly decline and by raising short-term interest rates. The decline in the Fed's balance sheet as a percentage of GDP followed the end of quantitative easing (QE3) in 2014. The FOMC chose to end new purchases in that program in the wake of a string of positive economic reports and nonfarm payroll gains in 2013-14. Figure 1 depicts the post-2014 decline in the Fed's balance sheet as a percentage of GDP. The prolonged divergence in policy direction underscores differences in economic conditions in the two countries. Such separation is a bit

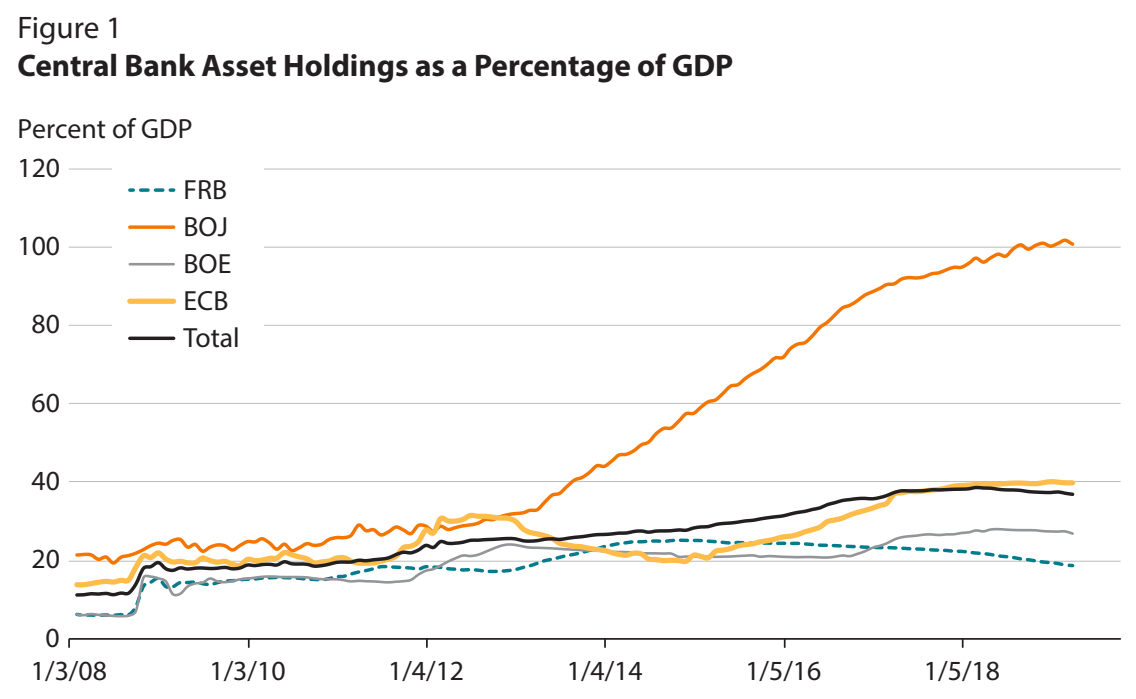

SOURCE: Bank of England (BOE), Bank of Japan (BOJ), European Central Bank (ECB), Federal Reserve Board (FRB), Organisation for Economic Co-operation and Development, Haver Analytics, FRED ${ }^{\circledR}$, and author's calculations. 
Figure 2

Japanese Interest Rates

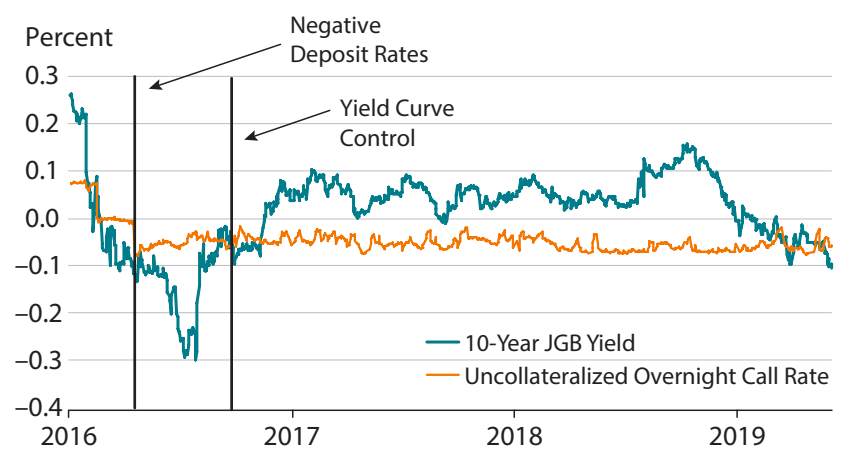

NOTE: JGB, Japanese government bonds.

SOURCE: Tullett Prebon Information, Bank of Japan, and Haver Analytics.

unusual for major central banks, which often face similar problems and react to those problems in a similar fashion.

In contrast to the Fed's reduction of accommodation in 2013-14, BOJ asset accumulation accelerated in 2013, following the election of Shinzo Abe as Prime Minister. On January 22, 2013, the government and BOJ jointly issued a statement that the BOJ would commence new asset purchases and double its inflation target from 1 to 2 percent to bolster inflation expectations. In January 2016, the BOJ supplemented these measures with a system of negative deposit rates on certain reserves held with the central bank. More radically, on September 21, 2016, the BOJ announced that it would begin to simultaneously target the uncollateralized overnight rate and the 10-year yield with a policy termed "Quantitative and Qualitative Easing with Yield Curve Control." The practice of targeting long yields was unprecedented in the recent history of major central banks. ${ }^{2}$ Figure 2 shows that the BOJ has been broadly successful in this endeavor, keeping overnight rates between 0 and -0.1 percent and 10-year Japanese government bond yields between -0.1 and 0.1 percent.

\section{Figure 3}

\section{Japanese Inflation}

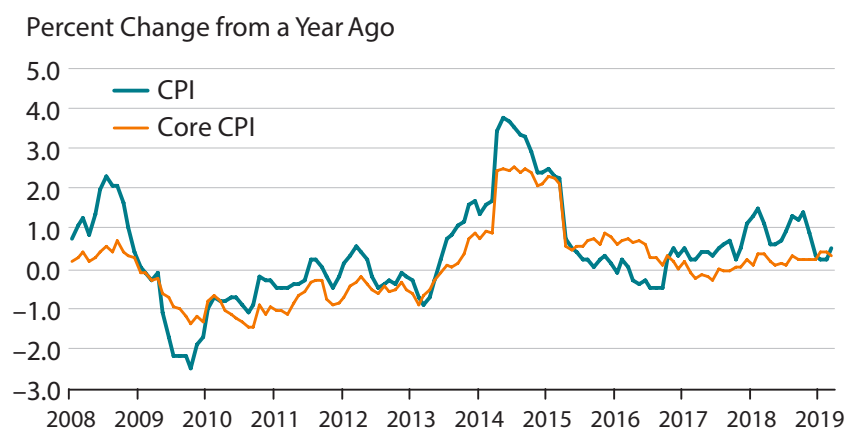

NOTE: $\mathrm{CPI}$, consumer price index.

SOURCE: Organisation for Economic Co-operation and Development and FRED ${ }^{\circ}$.

To control yields in this fashion, the BOJ purchased almost twice the net issuance of Japanese government bonds in 2017 and now owns 43 percent of the outstanding bonds. By purchasing large fractions of both the flow and stock of the bonds, the BOJ has effectively controlled long yields. The BOJ assets in Figure 1 reflect the accumulation of the bonds. These measures have not, however, successfully returned Japan's inflation rate to its 2 percent target. Instead, Figure 3 shows that Japanese inflation remains near zero. Many observers blame long entrenched expectations of static prices for this outcome.

\section{Notes}

1 The Swiss National Bank (SNB) holds an even greater percentage of assets relative to GDP, at about 118 percent. The SNB bought an unusually large quantity of assets in the form of foreign exchange in an attempt to stabilize its currency during the period.

2 Prior to the U.S. Treasury-Fed Accord of 1951, the Fed cooperated with the U.S. Treasury to fix long-term yields and thus minimize the costs of financing World War II. 